\title{
In good hands
}

Cite as: CMAJ 2017 April 24;189:E610-1. doi: 10.1503/cmaj.161251

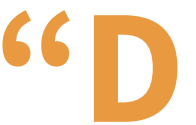

eath is not an event in life: we do not live to experience death .... Our life has no end in just the same way in which our visual field has no limits."

Ludwig Wittgenstein, $1922{ }^{1}$

I don't like my work any more. I do it because it has to be done. There is a need for it, so I do it. Yet, every night I have the same dream. Someone is suffocating me. In the dream, the only thing that changes each night is the hand over my mouth, the hand of the person I've killed that day.

But I am not a murderer: I am a physician. My job is to serve my patients. When their suffering becomes intolerable, I help them exit this world peacefully. I give them what they want: a gentle, dignified death. It's all above board.

More than a decade ago, it stopped being a crime for a physician to help a patient die. Around the same time, I joined the family practice of Dr. M.

"It's not why I went into medicine," he said to me one day as we were out making house calls on his "shut-ins." He saw this law as a threat and a burden.

I was not so certain. "What if the person is suffering horribly?"

"Suffer with the patient. Deliberately ending your patient's life is not in the Hippocratic oath," Dr. M insisted. He was definitely old school - the sacredness of life and all that. He assumed I would take the same moral high road.

Following his retirement, some of his patients, who had aged with him, began making requests for death.

There was 82-year-old Jack who had disfiguring, incurable head and neck cancer.

"Do everything!" he implored. He loved life and wanted to squeeze every moment out of it.

Then, after two years of quiescence,

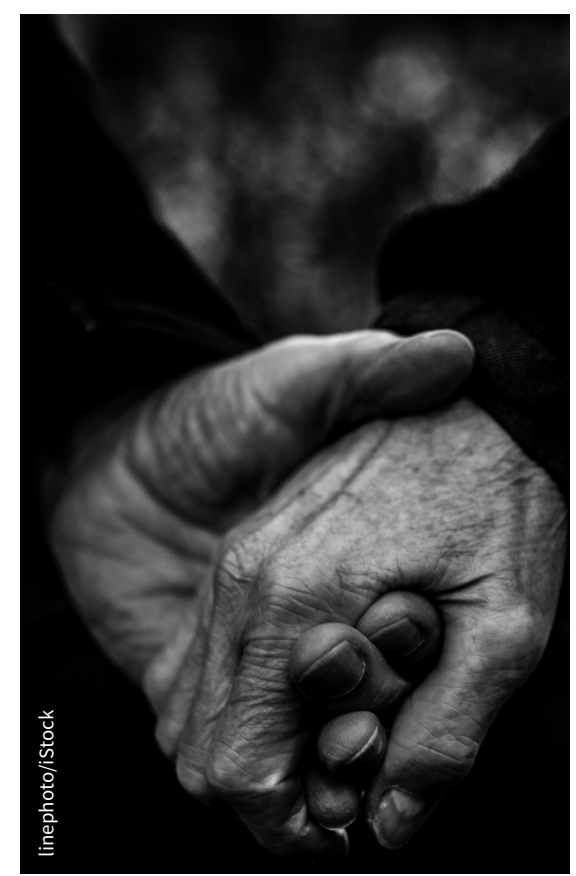

Jack's cancer recurred and advanced rapidly, ravaging his face. What the disease had not eaten away, surgery and radiation had destroyed. He could see the end coming - it just wasn't coming quickly enough for him. He also wanted to die where he had lived for half a century.

"Please, doctor, I've had enough. Can't you speed things up?"

"Sorry, Jack, I can't do that." Although I had nothing more to offer, I still asked if there was anything else I could do. There wasn't. When he became too ill for his caregivers to manage, he was admitted to acute care. He would die there. I felt I had failed him.

Then there was Lucille, a 96-year-old lawyer and a long-time advocate for doctor-assisted suicide, who had taken to bed because of generalized weakness.

"Oh, doctor, I'm so tired, can't you give me something so I don't wake up?" I demurred. "You need to eat more! Why don't we see if we can get you going with a little help from physiotherapy? Maybe some extra nursing care?"

Lucille had no interest in seeing any other health professionals.

She had been Dr. M's patient for many years; I clearly was not measuring up to his exacting standards. "Is that the best you could do?" I could hear him say about my paltry suggestions.

When I returned to see her the next week, her husband told me he had found her dead in bed that morning. "There was nothing that could be done, that's pretty obvious, as you'll see. I thought I'd just wait for you to come." Indeed, Lucille was quite obviously dead - the wall and bedspread was covered with a huge spray of blood she must have vomited up.

"I'm not really surprised," her husband told me, "she has looked very poorly for a long time." Asked if he wanted an autopsy, he shrugged his shoulders and headed toward the door. "What's the point?" he said.

Not seeing any point either, I called the funeral home to pick up Lucille's body. Inconceivably, I was concerned about how I would be seen by others. They probably thought I was an idiot for my uncertainty as to whether to call the coroner and what to write down as the cause of death.

I had to remind myself that this horrific death was about Lucille, not me. I could only imagine how terrifying dying must have been for her. She had died alone, miserably, without succor - and I had let it happen.

After Lucille's death, I found myself increasingly open to meeting requests from ailing patients for the means to end their lives. I joined the list of doctors recognized by the health authorities as able to provide the unique deadly drug cocktail. I would provide the lethal service that had influenced physicians like Dr. M 
to retire. No questions would be asked. No coroner would have to be told.

Because I had a good bedside manner and knew how to comfort the ill and suffering, my services began to be sought out. I found myself hastening death once or twice a week. Many of my colleagues were happy that I was prepared to do this work. The patient is the doctor's master, I said to myself, remembering a commentary from the New England Journal of Medicine. ${ }^{2}$

I came to see my service as part of routine care at the closure of life. I was not troubled by it. Indeed, I witnessed many good deaths - people dying peacefully at home, surrounded by family and friends. I got used to the requests ... for a while anyway. Until Ramon came along. I had entertained my doubts about helping other patients die, but, for some reason, these doubts crystallized when Ramon sought my help.

In his early 50s, married, with two teenagers, Ramon had been diagnosed with early-onset Alzheimer dementia a year earlier. Another doctor had written him a prescription for a lethal dose of pills, and he was seeing me to confirm the appropriateness of that prescription. The problem for me was that he was not terminally ill - at least as I understood it. What bothered Ramon were not reasons that I felt were good enough to take an early exit from life: increasing difficulties in finding words, recent memory loss and difficulty learning new skills. For example, he just could not figure out how to use his new cell phone.

"What's the rush, Ramon?" "I want to die now while I still have my boots on." Ramon was a stationary engineer and indeed had his boots on. The prospect of becoming dependent on his wife and two daughters bothered him enormously.

But when he added, "My family will be better off without me," I wanted to snatch the prescription back from him.
"So for exactly whom are you doing this?" I asked him. "For myself and my family," Ramon replied.

What he said and who he was raised questions as to what I was doing. Was the prevention of possible future suffering reason enough to help patients die? And whose suffering was I meant to alleviate: Was it always just the patient's? Was it the family's? The physician's? What if I were the patient? I was unsure what I would do or have done to me. I vowed to be even more vigilant. Ramon's request, which I reluctantly decided to go along with, ebbed away at my self-confidence.

For me the act of aiding death is almost a sacred act. When we meet to close the book of their lives, I take the patients' hands in mine. In their dying, their hands flutter and quiver, and then still and stiffen. My hands help their hands, and their deaths become part of my life. That's how it goes.

So, not surprisingly, it's my patients' hands I cannot forget. The rough and calloused hands of Albert, a manual labourer, dying of metastatic bladder cancer. The smooth and slender hands of Sarah, her brain riddled with multiple breast cancer metastases. The thin and wizened hands of Dennis, no longer able to swallow his own spit because of inoperable esophageal cancer.

I liked all of these patients. I think I understood their terrible suffering. But my work now seems like a bad habit: once I started, it was hard to stop. I chafe at the routineness of it all for some physicians, ${ }^{3}$ and the astonishingly thin expectations of some patients - for example, those who simply say they're "tired of life" and want it to end "two weeks from next Friday at $1 \mathrm{pm}$ " - as if death were a stop on a train schedule for which a seat can be booked, and the physician is merely a conductor collecting the ticket to ride. Maybe it is just too many deaths. Or the lives that seem too much like my own.

I know my service is needed; however, the doubts and weights of the past have become too heavy. My patients' hands have become too binding and, at night, I am unable to disentangle myself from them. I have helped some patients die who had good reason to die. But I also feel complicit in ending lives that may have been closed too soon - before I would have wanted to die or to have a loved one die. Assistance at death is all about autonomy, I know, but I worry about the lifeending mistakes I may have made. Guilt sits in my stomach like a hard stone.

These doubts about what I do have continued to well up in me. I am not entirely sure why. Over time, I have felt my morals becoming more like lines drawn in the sand on a beach. The next wave keeps washing them away.

What was not clear became clearer for a period and has now faded into a haze of grey. It is time for other hands to take over.

\section{Philip Hébert PhD MD}

Professor Emeritus, Department of Family and Community Medicine, University of Toronto, Toronto, Ont.

\section{References}

1. Wittgenstein L. Tractatus Logico-Philosophicus. London (UK): Routledge \& Kegan Paul; 1969:6. 4311.

2. Levinsky NG. The doctor's master. N Engl J Med 1984;311:1573-5.

3. Hébert PC. Good medicine: the art of ethical care in Canada - Stories of holding on and letting go for patients and the doctors who treat them. Toronto: Random House; 2016:155-72.

The details in this entirely fictional article are based upon experiences of real people that have been revised and anonymized to protect individuals' privacy. The author is indebted to Nancy Caroll at Wordreach, and to the many friends and colleagues who provided much needed assistance at earlier drafts of this paper. 